\title{
Acute Phase Proteins and Variables of Protein Metabolism in Dairy Cows during the Pre- and Postpartal Period
}

\author{
CS. TÓTHOVÁ, O. NAGY, H. SEIDEL, J. KONVIČNÁ, Z. FARKAŠOVÁ, G. KOVÁČ
}

II. Clinical Department for Internal Diseases, University of Veterinary Medicine, Košice, Slovak Republic

Received July 13, 2007

Accepted December 19, 2007

\begin{abstract}
Tóthová Cs., O. Nagy, H. Seidel, J. Konvičná, Z. Farkašová, G. Kováč: Acute Phase Proteins and Variables of Protein Metabolism in Dairy Cows during the Pre- and Postpartal Period. Acta Vet Brno 2008, 77: 51-57.

The objective of the present study was to compare the concentrations of acute phase proteins and selected variables of protein metabolism in dairy cows of the Slovak Spotted breed from 4 weeks before parturition to 10 weeks after parturition. Acute phase proteins - haptoglobin (Hp) and serum amyloid A (SAA) - and variables of protein metabolism - total proteins, albumin, urea, creatinine, total immunoglobulins - were evaluated in blood serum. Significant differences were found in average values of the $\mathrm{Hp}$ and SAA concentrations in several groups during the monitored period $(P<0.05$ and $P<0.001$, respectively). The Hp and SAA concentrations in cows during the early postparturient period were significantly higher compared with the later postparturient period. Throughout the monitored time we found differences in mean values of total proteins $(P<0.001)$, urea $(P<0.001)$, and total immunoglobulins $(P<0.05)$. The concentrations of albumin decreased progressively in the postparturient period until 4 weeks after parturition. In the assessment of correlations between the monitored variables in the mentioned period we found significant correlations between $\mathrm{Hp}$ and SAA $(\mathrm{r}=0.916 ; P<0.001)$, total proteins and urea $(\mathrm{r}$ $=0.668 ; P<0.05)$, total proteins and total immunoglobulins $(\mathrm{r}=0.827 ; P<0.01)$, and between total immunoglobulins and urea $(\mathrm{r}=0.899 ; P<0.001)$. The above mentioned results indicate that in the time around parturition there are significant changes in concentrations of acute phase proteins, as well as in the whole protein metabolism of dairy cows. These facts suggest that the postparturient period is a critical biological phase, throughout which there is the highest incidence of metabolic disorders.
\end{abstract}

Haptoglobin, serum amyloid A, periparturient period, protein profile

The transition (or periparturient) period is the most critical period in dairy cows regarding health status and production. The length of this important period has been defined differently by various authors. It constitutes late pregnancy and early lactation, generally 3 weeks before and 3 weeks after parturition (Grummer 1995). Most infectious diseases and metabolic disorders, such as milk fever, ketosis, fatty liver, displaced abomasum, retained placenta, and metritis occur in cows in this time (Stabel et al. 2003). Immunosuppression during this period leads to increased susceptibility to mastitis (Mallard et al. 1998). Thus, most health problems are centred disproportionately in this relatively short period. In consequence of suppression of the immune functions, the cows become less resistant to infectious diseases, big changes occur in the whole metabolism, and homeostasis is impaired. The animals respond to these changes with a sequence of physiological reactions. One of them is the acute phase response as a part of the general non-specific immune system. The host response to pathogens or injury starts through the activation of macrophages. Activated macrophages release a variety of products known as cytokines, the most important of which are TNF- $\alpha$, interleukin-1 and interleukin-6. Among other functions, these transmitter substances promote the production of a variety of proteins in the liver, such as serum amyloid A (SAA) and haptoglobin (Hp) (Edbrooke et al. 1991). It

Address for correspondence:

MVDr. Csilla Tóthová

II. Clinical Department for Internal Diseases

University of Veterinary Medicine

Komenského 73

04181 Košice, Slovak Republic

Phone: +421915984597

Fax: +421 552981011

E-mail: Tothova.C@azet.sk

http://www.vfu.cz/acta-vet/actavet.htm 
has been reported that monitoring the plasma concentration of acute phase proteins, such as SAA and Hp, provides a valuable diagnostic information on cattle conditions (Eckersall 2000), to discriminate between cattle with acute and sub-clinical or chronic respiratory diseases (Godson et al. 1996) and to detect cows with clinical mastitis (Eckersall et al. 2001). Kováč et al. (2007) reported also that the measurements of the acute phase proteins, haptoglobin and serum amyloid A, predominantly in milk, may be useful in monitoring udder health. In general, the time around calving is considered to be a critical period with a negative impact on the energy and protein metabolism (Kováč 2001). The aim of this study was to evaluate the concentrations of selected acute phase proteins - haptoglobin and serum amyloid A - in the blood serum of dairy cows in relation to different phases of the reproduction cycle, as well as to some variables of protein metabolism.

\section{Materials and Methods}

Selected acute phase proteins - haptoglobin ( $\mathrm{Hp})$ and serum amyloid A (SAA) - and selected variables of protein metabolism - total proteins (TP), albumin (Alb), urea (U), creatinine (CR), total immunoglobulins (TIg) - were evaluated in 64 dairy cows of the Slovak Spotted breed and its crossbreeds. The animals were fed $2 \times$ daily with a feeding ration according to the phase of lactation and milk production. The dairy cows had free access to drinking water. The animals were divided into 9 groups according to certain phases of antepartal and postpartal period:

Group 1 - dairy cows 4 weeks before parturition $(n=6)$

Group 2 - dairy cows 1 week before parturition $(\mathrm{n}=8)$

Group 3 - dairy cows 1 week after parturition $\quad(n=6)$

Group 4 - dairy cows 2 weeks after parturition $\quad(n=11)$

Group 5 - dairy cows 3 weeks after parturition $(n=7)$

Group 6 - dairy cows 4 weeks after parturition $\quad(n=6)$

Group 7 - dairy cows 5 weeks after parturition $(n=6)$

Group 8 - dairy cows 8 weeks after parturition $\quad(n=7)$

Group 9 - dairy cows 10 weeks after parturition $(\mathrm{n}=7)$

All the evaluated variables were analyzed in blood serum. The blood samples were collected by direct puncture of $v$. jugularis. Before each sample collection, the animals were clinically examined by standard clinical examination procedures (Slanina et al. 1993). The values of TP, Alb, U and CR were assessed using commercial diagnostic kits (Randox) and automatic biochemical analyser (Alizé, Lisabio). TIg were analyzed by spectrophotometric turbidimetric method (zinc-sulphate test). The determinations of Hp and SAA were performed by the method of enzyme linked immunosorbent assay (ELISA) using ELISA kits (Tridelta Development, Ltd., Wicklow, Ireland) in microplates. The readings of absorbance and the consecutive calculations of final concentrations were performed on the automatic microplate reader Opsys MR (Dynex Technologies).

Evaluation of the obtained results was performed by the assessment of mean values (x) and standard deviations (S.D.) in each monitored group of dairy cows. The significance of differences in average values in relation to several monitored periods was evaluated by one way analysis of variance (ANOVA). The significance of differences in average values between the groups was evaluated by unpaired Student's $t$-test. The correlations between monitored variables were evaluated at the same time (r).

\section{Results}

Results of the assessment of Hp and SAA concentrations and concentrations of variables of protein metabolism are presented in Table 1. The analyses of correlations between monitored variables are listed in Table 2.

In a short time before calving and in the early postparturient period we recorded higher $\mathrm{Hp}$ and SAA concentrations in dairy cows compared with the later postparturient period, in which the highest average values (346.64 and $127.83 \mu \mathrm{g} / \mathrm{ml}$, respectively) were found in the cows 1 week after parturition. In the cows 2 weeks after parturition (Group 4) we observed significantly lower SAA concentration $(P<0.05)$ than in the cows 1 week after calving. Compared with the cows 1 week after calving, significantly lower average Hp values $(P<0.05)$ were determined in the cows 3 weeks after parturition. The differences in average values of $\mathrm{Hp}$ and SAA concentrations during the monitored period in the groups of dairy cows were significant (ANOVA - $P<0.05$ and $P<0.001$, respectively). Statistically significant differences of the average values during the monitored period were found also in 


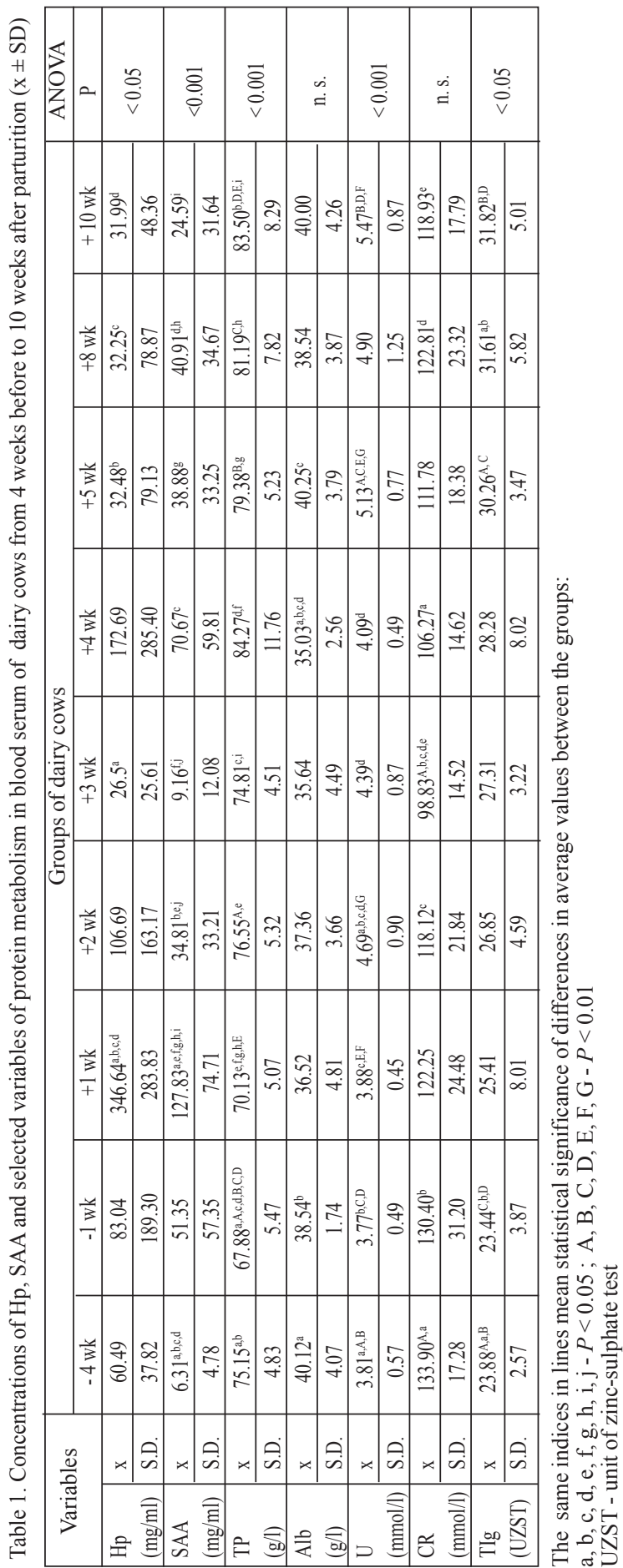

total proteins $(P<0.001)$, urea $(P<$ $0.001)$, and total immunoglobulins $(P<0.05)$. TP concentrations in the early postparturient period were approximately uniform; significantly higher values $(P<$ 0.05 and $P<0.01)$ compared with the cows before calving (Groups 1 and 2) were found in cows in the later postparturient period (Groups 6 - 9). In TIg concentrations we observed significantly lower values in the cows before calving and in the early postparturient period than was determined post partum (Groups 7 - 9; $P<0.05$ and $P<0.01)$. The highest average concentration of 31.82 UZST was recorded in the cows 10 weeks after parturition. In the case of Alb and CR we found an opposed tendency, their concentrations in the blood serum of cows in the time before calving were significantly higher than the values recorded early after calving, and the lowest values were determined 4 and 3 weeks after parturition, respectively. Urea concentrations were found slightly higher after parturition than before parturition, significantly higher concentrations compared with the cows before calving were recorded in the cows 5 and 10 weeks post partum $(P<0.01)$.

By assessment of correlation (Table 2) between monitored acute phase proteins, we recorded their significant correlation $(\mathrm{r}=$ $0.916 ; P<0.001$ ). By evaluation of correlation between monitored variables of protein metabolism we found a significant correlation between TP and $\mathrm{U}(\mathrm{r}=0.668$; $P<0.05)$, TP and TIg $(\mathrm{r}=0.827$; $P<0.01$ ), and between TIg and $\mathrm{U}$ ( $\mathrm{r}=0.899 ; P<0.001)$. Between monitored acute phase proteins and individual variables of protein metabolism no significant correlations were determined. 
Table 2. The correlations between selected acute phase proteins and variables of protein metabolism

\begin{tabular}{|l|c|c|c|c|c|c|c|}
\hline & Hp & SAA & TP & Alb & U & CR & TIg \\
\hline Hp & - & $0.916^{\mathrm{c}}$ & -0.354 & -0.499 & -0.525 & 0.093 & -0.394 \\
\hline SAA & $0.916^{\mathrm{c}}$ & - & -0.269 & -0.417 & -0.344 & 0.061 & -0.169 \\
\hline TP & -0.354 & -0.269 & - & 0.065 & $0.668^{\mathrm{a}}$ & -0.403 & $0.827^{\mathrm{b}}$ \\
\hline Alb & -0.499 & -0.417 & 0.065 & - & 0.407 & 0.595 & 0.189 \\
\hline U & -0.525 & -0.344 & $0.668^{\mathrm{a}}$ & 0.407 & - & -0.303 & $0.899^{\mathrm{c}}$ \\
\hline CR & 0.093 & 0.061 & -0.403 & 0.595 & -0.303 & - & -0.410 \\
\hline TIg & -0.394 & -0.169 & $0.827^{\mathrm{b}}$ & 0.189 & $0.899^{\mathrm{c}}$ & -0.410 & - \\
\hline
\end{tabular}

Statistical significance of correlations: $\mathrm{a}-P<0.05, \mathrm{~b}-P<0.01, \mathrm{c}-\mathrm{P}<0.001$

Clinical examinations of the cows before calving did not reveal any disorders of the general health condition. In the cows 1 week after parturition (Group 3) we did not observe marked clinical changes in the reproductive system, except for one cow that had a mucopurulent discharge from the vagina. The cows 2 weeks after calving were without clinical signs of reproductive disorders. In three cows 3 weeks after parturition (Group 5) we recorded a mucopurulent discharge from the vagina. In one cow 4 weeks after calving dyspnoea was observed, and in one animal 5 weeks after parturition we found a mucopurulent nasal discharge. In the later postparturient period, in one cow 8 weeks and in one cow 10 weeks after calving lameness was observed.

\section{Discussion}

The production of acute phase proteins is induced by inflammatory processes, transport, stress, starvation or exhaustion of organism (Uchida et al. 1993). The role of the acute phase response is to isolate and neutralize pathogens, prevent their further spreading, minimize tissue damage, and promote repair processes, and to restore a healthy physiological function (Kushner 1982). Saini et al. (1998) reported that lactation and pregnancy in cattle appeared to have no effect on the Hp concentration in blood serum. However, according to Gymnich et al. (2003) haptoglobin concentrations undergo significant changes around parturition and in horses and cows the highest concentrations were observed 1 day post partum. Uchida et al. (1993) evaluated the concentration of Hp in cows in the periparturient period and similarly to our results they observed significantly higher values around parturition than before and after parturition. The concentration of SAA increases in the blood serum of dairy cows directly after parturition (Alsemgeest et al. 1993). Similarly, Ametaj (2005) reported that immediately after parturition there is an increase of two main acute phase proteins in cattle, Hp and SAA. We observed non-significantly higher concentrations of these proteins as far back as one week before parturition.

Postpartum endometritis is a common problem in cattle, because uterine contamination following calving is frequent, but most cows are able to eliminate bacteria from the uterus within 2 to 3 weeks after calving without manifesting marked clinical signs of the disease. However, cows that can not eliminate the infection may subsequently develop endometritis. Hirvonen et al. (1999) reported that Hp concentrations are high in cows with mastitis, metritis, and other inflammatory processes. Chan et al. (2004) evaluated clinically healthy cows and cows with postpartum reproductive diseases after calving, and $\mathrm{Hp}$ concentrations in clinically diseased cows $\left(1133.5 \mathrm{mg} \cdot \mathrm{l}^{-1} \pm 627.1 \mathrm{mg} \cdot \mathrm{l}^{-1}\right)$ were significantly higher than in clinically healthy cows $\left(104.6 \mathrm{mg} \cdot 1^{-1} \pm 61.0 \mathrm{mg} \cdot \mathrm{l}^{-1}\right)$. However, postpartum metritis does not necessarily need to be manifested by general clinical signs of the disease; frequently only subfertility and a decrease of the milk yield are found. Moreover, various cows with mild uterine inflammation are able to spontaneously restore health without more serious consequences. This is indicated also by our observations; we found higher Hp and SAA 
concentrations in the dairy cows in the early postpartum period, although we did not record clinically evident changes in the reproductive system. Higher values of the mentioned variables, despite the absence of clinical signs, may also represent cases with previous or mild inflammatory conditions, or severe stress. These facts support the theory that observation of the concentration of acute phase proteins may be particularly useful as an early detection method for some postpartum reproductive diseases (Chan et al. 2004).

Albumins are a group of proteins constituting approximately $60 \%$ of proteins in blood plasma. Albumins are important in regulating blood volume by maintaining the osmotic pressure of the blood and transporting fatty acids, non-conjugated bilirubin, and some steroid hormones. Serum albumin concentrations decrease in acute disease states. For this reason albumin is sometimes referred to as the negative acute phase protein (Petersen et al. 2004). On the other hand, since albumins are synthesized in the liver, low serum concentrations may be indicative of chronic hepatitis. Pechová et al. (2002) observed dairy cows from 2 weeks before calving until 5 weeks after calving, during which time the concentrations of albumin were uniform and did not exceed the physiological range. We recorded lower concentrations of this variable in the early postparturient period than before calving and in the later postparturient period; the lowest value of $35.03 \mathrm{~g} / 1$ was found in the dairy cows 4 weeks after parturition.

Large changes in the immune response occur around calving, as well. Parturition influences the ratio of blood lymphocytes and their functional activities. The main function of B-lymphocytes is differentiation into plasma cells, which have the capacity to secrete Ig. Despite the changes detected around calving in the ratio of T-cells, the percentage of B-lymphocytes seems to remain constant (Shafer-Weaver et al. 1996). In contrast, Van Kampen and Mallard (1997) reported that before and around parturition there are fewer B-cells in blood than after parturition. In regard to the functional activity of B-cells, a diminished antibody production during the time of parturition has been observed. Our results also indicate that in the periparturient period the concentration of total immunoglobulins in blood is lower and there is a repeated increase of their values in the later postparturient period. Fatty liver may further decrease the function of the immune system (Breukink et al. 1997). Katoh (2002) suggested that accumulation of lipids in the liver can affect the immune response directly by altering the ability of the liver to synthesize compounds involved in the immune response. Increased hepatic triglyceride concentration is associated with a decreased function of lymphocytes (Lacetera et al. 2005). Lymphocytes from overconditioned cows secrete less IgM after calving and less interferon- $\gamma$ before calving than the cells from cows in moderate or thin body condition.

Total proteins represent the total amount of proteins in blood serum. Protein measurements may reflect the nutritional state, kidney diseases, liver diseases, and other conditions. Mordak and Nicpoń (2006) observed lower total protein concentrations in the postparturient period. Lower total protein concentrations may indicate malabsorption, malnutrition, agammaglobulinaemia, glomerulonephritis, as well as liver diseases. These mentioned decreases may be caused also by the transfer of albumin and $\gamma$-globulins from blood to the mammary gland (Kupczyński and Chudoba-Drozdowska 2002). Our results comply with these findings, forasmuch as in the later period after calving we recorded significantly higher total protein concentrations than in the early postparturient period.

In conclusion, our results indicate that at the time around calving there are significant changes in concentrations of acute phase proteins, as well as in the whole protein metabolism of dairy cows. In the monitored period we recorded significant changes of their values, as well as some important correlations. As we found higher Hp and SAA concentrations in cows without clinically evident changes in the reproductive system, the determination of these proteins during the first days after parturition could be used for diagnosis of the early 
stages of postpartal inflammatory diseases in cows, thus enabling initiation of therapy at a time when clinical symptoms are absent.

\section{Proteíny akútnej fázy a parametre bielkovinového profilu u dojníc počas pre- a postpartálneho obdobia}

V štúdiu sme sa zamerali na porovnanie koncentrácie proteínov akútnej fázy a vybraných ukazovatel'ov bielkovinového profilu u dojníc slovenského strakatého dobytka v období od 4 týždňov pred pôrodom do 10 týždňov po pôrode. Proteíny akútnej fázy - haptoglobín (Hp) a sérový amyloid A (SAA) - a ukazovatele bielkovinového profilu - celkové proteíny, albumín, urea, kreatinín, celkové imunoglobulíny - boli stanovované v krvnom sére. Zaznamenali sme významné rozdiely priemerných hodnôt koncentrácie Hp a SAA v jednotlivých skupinách počas sledovaného obdobia $(P<0,05$, resp. $P<0,001)$. Koncentrácie Hp a SAA u dojníc $\mathrm{v}$ ranom popôrodnom období boli signifikantne vyššie v porovnaní s neskorším postpartálnym obdobím. Významné rozdiely priemerných hodnôt počas sledovania sme zistili aj u celkových bielkovín $(P<0,001)$, urey $(P<0,001)$ a celkových imunoglobulínov $(P<0,05)$. Koncentrácia albumínu sa postupne znižovala $\mathrm{v}$ popôrodnom období až do 4. týždňa po pôrode. Pri hodnotení korelačných vzt'ahov medzi sledovanými ukazovatel'mi v uvedenom časovom období bola zistená významná korelácia medzi Hp a SAA $(\mathrm{r}=0,916 ; P<0,001)$, celkovými bielkovinami a ureou $(\mathrm{r}=0,668 ; P<0,05)$, celkovými bielkovinami a celkovými imunoglobulínmi $(\mathrm{r}=0,827 ; P<0,01)$, a medzi celkovými imunoglobulínmi a ureou $(\mathrm{r}=0,899 ; P<0,001)$. Vyššie uvedené výsledky poukazujú na to, že v období okolo pôrodu dochádza k významným zmenám v koncentrácii proteínov akútnej fázy, ako aj v celom bielkovinovom metabolizme dojníc. Tieto skutočnosti poukazujú na to, že popôrodné obdobie je kritickou biologickou fázou, počas ktorej býva aj najvyššia incidencia metabolických porúch.

\section{Acknowledgment}

This work was supported by the Slovak Research and Development Agency under the contract No. APVV20-027905.

\section{References}

AMETAJ BN 2005: A new understanding of the causes of fatty liver in dairy cows. Adv Dairy Technol 17: 97-112

ALSEMGEEST SPM, TAVERNE MAM, BOOSMAN R, VAN DER WEYDEN BC, GRUYS E 1993: Peripartum acute-phase protein serum amyloid-A concentration in plasma of cows and fetuses. Am J Vet Res 54: 164-167

BREUKINK HJ, WENSING TH 1997: Pathophysiology of the liver in high yielding dairy cows and its consequences for health and production. Isr J Vet Med 52: 66-72

CHAN JPW, CHU CC, FUNG HP, CHUANG ST, LIN YC, CHU RM, LEE SL 2004: Serum haptoglobin concentration in cattle. J Vet Med Sci 66: 43-46

ECKERSALL PD 2000: Recent advances and future prospects for the use of acute phase proteins as markers of disease in animals. Revue Méd Vét 151: 577-584

ECKERSALL PD, YOUNG FJ, MCCOMB C, HOGARTH CJ, SAFI S, FITZPATRICK JL, NOLAN AM, WEBER A, MCDONALD T 2001: Acute phase proteins in serum and milk from dairy cows with clinical mastitis. Vet Rec 148: 35-41

EDBROOKE MR, FOLDI J, CHESHIRE JK, LI F, FAULKES DJ, WOO P 1991: Constitutive and NF-kappa Blike proteins in the regulation of the serum amyloid A gene by interleukin 1. Cytokine 3: 380-388

GODSON DL, CAMPOS M, ATTAH-POKU SK, REDMOND MJ, CORDEIRO DM, SETHI MS, HARLAND RJ, BABIUK LA 1996: Serum haptoglobin as an indicator of the acute phase response in bovine respiratory disease. Vet Immunol Immunopathol 51: 277-292

GRUMMER RR 1995: Impact of changes in organic nutrient metabolism on feeding the transition dairy cow. J Anim Sci 73: 2820-2833

GYMNICH S, HISS S, SAUERWEIN H, PETERSEN B 2003: Haptoglobin in sows at parturition. Proceedings of the $4^{\text {th }}$ European Colloquium on Food Safety and Acute Phase Proteins. Segovia, Spain, 136 p.

HIRVONEN J, EKLUND K, TEPPO AM, HUSZENICZA G, KULCSAR M, ALONIEMI H, PYORALA S 1999: Acute phase response in dairy cows with experimentally induced Escherichia coli mastitis. Acta Vet Scand 40: $35-46$ 
KATOH N 2002: Relevance of alipoproteins in the development of fatty liver and fatty liver-related peripartum diseases in dairy cows. J Vet Med Sci 64: 293-307

KOVÁČ G 2001: Choroby hovädzieho dobytka (Cattle diseases), (in Slovak). Vydavatel'stvo M\&M, Prešov, $874 \mathrm{p}$.

KOVÁČ G, POPELKOVÁ M, TKÁČIKOVÁ L', BURDOVÁ O, IHNÁT O 2007: Interrelationship between somatic cell count and acute phase proteins in serum and milk of dairy cows. Acta Vet Brno 76: 51-57

KUPCZYŃSKI R, CHUDOBA-DROZDOWSKA B 2002: Values of selected biochemical parameters of cows blood during their drying-off and the beginning of lactation. Electr J Pol Agr Univ-Vet Med 5: available online: http://www.ejpau.media.pl/volume5/issue1/veterinary/art-01.html/\#streszczenie. Accessed on 13. 3. 2007

KUSHNER I 1982: The phenomenon of the acute phase response. Ann NY Acad Sci 389: 39-48

LACETERA N, SCALIA D, BERNABUCCI U, RONCHI B, PIRAZZI D, NARDONE A 2005: Lymphocyte functions in overconditioned cows around parturition. J Dairy Sci 88: 2010-2016

MALLARD BA, DEKKERS JC, IRELAND MJ, LESLIE KE, SHARIF S, VAN KAMPEN CL, WAGTER L, WILKIE BN 1998: Alteration in immune responsiveness during the peripartum period and its ramification on dairy cow and calf health. J Dairy Sci 81: 585-595

MORDAK R, NICPOŃ J 2006: Values of some blood parameters in dairy cows before and after delivery as a diagnostic monitoring of health in herd. Electr J Pol Agr Univ-Vet Med 9: available online: http://www.ejpau. media.pl/volume9/issue2/art-20html. Accessed on 14. 2. 2007

PECHOVÁ A, PODHORSKÝ A, LOKAJOVÁ E, PAVLATA L, ILLEK J 2002: Metabolic effects of chromium supplementation in dairy cows in the peripartal period. Acta Vet Brno 71: 9-18

PETERSEN HH, NIELSEN JP, HEEGAARD PMH 2004: Application of acute phase protein measurements in veterinary clinical chemistry. Vet Res 35: 163-187

SAINI PK, RIAZ M, WEBERT DW, ECKERSALL PD, YOUNG CR, STANKER LH, CHAKRABARTI E, JUDKINS JC 1998: Development of a simple enzyme immunoassay for blood haptoglobin concentration in cattle and its application in improving food safety. Am J Vet Res 59: 1101-1107

SHAFER-WEAVER KA, PIGHETTI GM, SORDILLO LM 1996: Diminished mammary gland lymphocyte functions parallel shifts in trafficking patterns during the postpartum period. Proc Soc Exp Biol Med 212: 2711-280

SLANINA L', DVOŘÁK R, BARTKO P, HANÁK J 1993: Veterinárna klinická diagnostika vnútorných chorôb. (Veterinary clinical diagnosis of internal diseases), (in Slovak). Príroda, Bratislava, $390 \mathrm{p}$.

STABEL JR, GOFF JP, KIMURAK 2003: Effects of supplemental energy on metabolic and immune measurements in periparturient dairy cows with Johne's disease. J Dairy Sci 86: 3527-3535

UCHIDA E, KATOH N, TAKAHASHI K 1993: Appearance of haptoglobin in serum from cows at parturition. J Vet Med Sci 55: 893-894

VAN KAMPEN C, MALLARD BA 1997: Effects of peripartum stress and health on circulating bovine lymphocyte subsets. Vet Immunol and Immunopathol 59: 79-91 
